\title{
SECURED LAND RIGHTS, HOUSEHOLD WELFARE AND AGRICULTURAL PRODUCTIVITY: EVIDENCE FROM RURAL PAKISTAN
}

\author{
Rakhshanda Kousar ${ }^{1, *}$, Muhammad Sohail Amjad Makhdum² and Qasir Abbas ${ }^{1}$ \\ ${ }^{1}$ Institute of Agricultural and Resource Economics, University of Agriculture Faisalabad, Pakistan; \\ ${ }^{2}$ Department of Economics, Government College University Faisalabad, Pakistan \\ *Corresponding author's e-mail: rakhshanda.kousar@uaf.edu.pk
}

\begin{abstract}
Land has a strategic position in rural areas because of its multidimensional roles but its distribution is unequal. This article evaluates the impact of secured property rights on per head expenditures, crop and livestock productivity, and poverty status of rural households. Information was collected from 341 rural households of Punjab Province of Pakistan. The study proceeds in two steps. At first, the linear probability model was employed to find the factors of tenancy arrangements. The results show that mostly the males were owner of the land, more educated and having more physical assets but fixed-rent farmers were mostly female, less educated and having fewer assets. Second, the study uses the predicted linear probability as instrument in the second stage. The results however show that secured property rights tend to enhance per head expenditures and farm productivity and reduce the household poverty. Other results show that education and ownership of farm land have positive and significant impact on per head expenditures whereas, farm productivity have negative and significant impact on poverty level. Policy makers should focus to improve the access to land, which is critical to improve welfare and reduce poverty. In recognition of this finding, we suggest that there is need to revisit the issue of land tenure security and access to credit by formulating and implementing land reforms in Pakistan.
\end{abstract}

Keywords: Crop productivity, land tenancy, livestock, poverty, household welfare.

\section{INTRODUCTION}

One of the key challenges in the developing countries is to enhance the productivity of small-scale farming, which is the main source of income and poverty reduction strategy for poor rural households. The poor households are unable to smooth their consumption and investment decisions because of liquidity constraints as a result of insecure property rights. The secured property rights provide incentives for farmers to stimulate long-term investments in agriculture to increase productivity, which in turn helps in economic viability, poverty reduction and investments in soil due to the assurance effect, transaction effect and access to credit.

Land has a strategic position in rural areas because of its multidimensional roles: key factor in production, collateral in credit markets, security against natural disasters or shocks, and symbol of social, economic and political prestige. Although, land is the major asset of farm families in rural areas of Pakistan, but its distribution is highly unequal. Ownership insecurity and land fragmentation is widespread in Pakistan, as is the case in other developing countries. For instance, 85 percent of farms are less than 12.5 acres which are under the control of small and medium farmers (Agricultural Statistics of Pakistan, 2012). Therefore, land leasing markets are working effectively in the country, with large land owners hiring labor or leasing their land to tenants to release themselves and their families from manual labor (Rehman, 1987). The major tenancy types in the study area are ownership, sharecropping and fix-renter. Among these, the most popular one is ownership, which gives full rights of utilizing, renting out and selling of land to farmers. In fixedrent tenancy type, landowners rent out their parcel of land to tenants who are residents or migrants at some fixed price for some set amount of time (usually one cropping season or one year). This tenancy arrangement is based on the agreement between owner and a tenant on the price of land and period of renting. However, there is also an agreement of sharing output and costs between landlord and tenant. In the rural setting, it is difficult to survive for the poor rural households because of asymmetric land distribution and rapid population growth, which lead to poverty and malnutrition as they are highly related to the landlessness (USAID, 2010).

Livestock is a very important component of rural community in Pakistan. It plays a very significant role for rural households in their subsistence and alleviating poverty by providing food, fiber, traction power, income security, medium of exchange, source of investment and other byproducts. It contributes approximately 56.3 percent to the agricultural value added and around 11.8 percent to the national GDP (GOP, 2015). 
Several studies have investigated the role of secured property rights on land investment, input use, and farm productivity. However, very few have analyzed the link between the ownership security and household welfare. This study seeks to contribute to the literature by assessing the impact of secured property rights on household poverty, per head expenditures and farm productivity by employing Instrumental variable approach that accounts for selfselection bias. The key objectives of the study are to analyze the determinants of land tenancy arrangements and estimation of the impact of ownership security on crop and livestock productivity, per head expenditures and poverty status of the households.

Conceptual Framework: Within the context of market imperfections, the significance of tenancy arrangement for stimulating the growth in agriculture has long been acknowledged in the empirical and theoretical literature. Deininger et al. (2009) noted that in the presence of imperfections in the labor and credit markets where land transfers involve transaction cost, land rental markets are not efficient enough to gain socially optimal outcome.

In the presence of credit market imperfections, farm households face liquidity constraint in farm investment. Similarly, ownership security provides incentive for farmers to engage in long-term investment measures in many ways. First, the secure tenancy improves the credit availability of households to finance agricultural investments by using land title as collateral. As Feder and Feeny (1991) demonstrated that in the presence of credit constraints, ownership security results in greater investment by providing access to credit. Second, secure tenancy increases the possibilities for trade in recovering full value of the land by making it easier for farmers to liquidate their land in the case of exogenous shocks (Ayalew et al., 2005; Deininger and Jin, 2006). The role of the media is also can promote this with lite bit effort. (javaid, 2017).

Although land ownership security tends to boost investment in soil-quality, enhances productivity and spurs resource management practices, but intensity of these investment practices depends on the nature of land contracts, suggesting that while making investment decisions, farmers consider tenure implications. Hence tenancy arrangements for the long duration are a significant agent for long-term land investment. As Kousar and Abdulai (2015) pointed out that fix-rent farmers with short-term contract have fewer incentives to engage in long-term soil improving practices, but have more interest to get benefits from short-term measures.

Thus, tenants tend to invest in the soil-quality up to the point where marginal profits are equal to zero and do not consider the depreciation cost of the soil.

Based on above theoretical concepts, we formulate two hypotheses about the relationship between tenancy arrangement, agriculture productivity and household welfare.
First hypothesis is that secured tenancy leads to enhance farm productivity and household welfare. Second hypothesis states that insecurity in land rights tends to decrease farm productivity and household welfare.

\section{MATERIALS AND METHODS}

Estimation strategy: In this study, we employed a reducedform approach that is less data-intensive, but still includes the production relationships. Reduced-form specification is under:

$$
\mathrm{Y}_{\mathrm{i}}=\beta \mathrm{T}_{\mathrm{iA}}+\psi \mathrm{Zi}+\varepsilon_{\mathrm{i}}
$$

where $Y_{i}$ represents outcome like crop productivity, livestock productivity, per head expenditures and poverty. The vector $T_{i}$ represents tenancy contracts and subscript A includes the variables $\lambda$ and $\gamma$ which represent output sharing rule between the owner, sharecropper and fixed-renter. $Z_{\mathrm{i}}$ is the individual and household level characteristics, $\varepsilon_{\mathrm{i}}$ is the error term.

The first-stage estimates of the determinants of tenancy arrangements are estimated by employing linear probability model. The omitted category used as a reference group is the sharecropping variable for tenancy arrangements. The tenancy contract variables are exogenous so, we employ instrumental variable approach in the second stage to estimate the impact of land tenancy arrangement on farm productivity and household welfare.

Proper identification of the model requires that some of the variables included in the first-stage estimation of tenancy contract regressions be excluded from second stage estimation. For this regard, we use the distance of the farm from the farmer's residence and a dummy variable indicating whether cultivator resides in the village where the farm is located or not as instruments.

Data description: The data for this study were collected during 2014 from Punjab province of Pakistan. Punjab is the second largest and most populous province of Pakistan, and contributes about 68 percent to annual food production. A stratified random sampling approach was used to collect information from 341 households from six districts: Sahiwal, Layyah, Sialkot, Khushab, Muzaffargarh, and Lahore. There exists asymmetry in the land ownership and have small ownership.

Table 1 displays the definitions of the variables used in the analysis. The dependent variable in the study is crop and livestock productivity, per head expenditures and poverty level of rural household. The three tenancy arrangement variables used are owner-cultivated, fixed-rent and sharecropping contracts. The value of crop produces is used because of the various types of the crops. Similarly, the value of livestock products and by-products is considered as livestock productivity. To avoid confounding a potential increase in productivity from increased output with returns to storage, we value output at producer prices at the time of 
Table 1. Descriptive statistics of variables used in the analysis.

\begin{tabular}{llrr}
\hline Variable & Definition of variables & Mean & S.D \\
\hline Owner & 1 if land is under owner-cultivated, 0 otherwise & 0.59 & 0.50 \\
Fix-renter & 1 if land is under fixed-rent contract, 0 otherwise & 0.26 & 0.44 \\
Sharecropper & 1 if land is under sharecropping contract, 0 otherwise & 0.15 & 0.23 \\
Age & Age of HH head in years & 45.87 & 13.30 \\
Gender & 1 if female is the head of HH, 0 otherwise & 0.20 & 0.23 \\
Education & Years of education of HH head & 8.22 & 6.28 \\
Family Size & Total no. of HH members between 14-60 years (working age group) & 4.02 & 2.89 \\
Animals & 1 if HH has livestock, 0 otherwise & 0.86 & 0.58 \\
Credit & 1 if HH has access to credit, 0 otherwise & 0.58 & 0.47 \\
Land & Total cultivated land in acres & 22.83 & 38.71 \\
Soil Quality & 1 if land is fertile, 0 otherwise & 0.73 & 0.36 \\
Distance & Distance of farm from owner's residence (km) & 1.99 & 4.12 \\
Residence & 1 if landlord reside in village where farm is located,0 otherwise & 0.54 & 0.43 \\
Location 1 & 1 if HH resides in Lahore district, 0 otherwise & 0.15 & 0.36 \\
Location 2 & 1 if HH resides in Sahiwal district, 0 otherwise & 0.20 & 0.39 \\
Location 3 & 1 if HH resides in Muzaffargarh district, 0 otherwise & 0.30 & 0.46 \\
Location 4 & 1 if HH resides in Layyah district, 0 otherwise & 0.02 & 0.13 \\
Location 5 & 1 if HH resides in Sialkot district, 0 otherwise & 0.25 & 0.43 \\
Location 6 & 1 if HH resides in Khushab district, 0 otherwise & 0.08 & 0.27 \\
\hline
\end{tabular}

harvest. The sample consisted of 200 owner-cultivated, 91 sharecropping and 50 fixed-rental households, without any recorded cases of households with multiple tenancy arrangements.

\section{RESULTS AND DISCUSSION}

The determinants of land tenancy arrangement are presented in Table 2. The estimates reveal that farm and household characteristics are related to tenancy arrangements. Males were mostly owner while fixed-rent farmers were mostly female. Owners are more educated, having more physical assets while fixed-rent tenants are less educated and having fewer assets. Owners were mostly residing in the village where their land was located. Similarly, owners cultivate land that was at less distance from their residence while land was located at far distance in the case of fixed-renters. This is due to the transportation and monitoring cost involved in managing land.

Table 3 shows the results of the instrumental variable analysis that capture the impact of land tenancy arrangement on per head expenditures, poverty and farm productivity show that secured property rights tend to enhance per head expenditures and farm productivity and reduce the household poverty level. The coefficients for the variables representing both, owners and fixed renters are positive and significant for crop and livestock productivity, and that for per head expenditures is negative and significant for poverty, suggesting that on-farm productivity and welfare are higher while poverty level is less under these tenancy arrangements, compared to sharecropping contracts, even after adjusting for other factors.
These results provide evidence in support of the Marshallian inefficiency hypothesis, whereby sharecroppers are less efficient than owner-cultivators and fixed renters, since they receive only a share of the marginal output at a given level of input use. The findings are consistent with those reported by Kousar and Abdulai (2015), who found positive and significant impacts of tenure security on productivity in their study.

Table 2. Linear probability estimates of determinants of land tenure arrangements.

\begin{tabular}{lcccc}
\hline Variable & Owner & $\begin{array}{c}\text { Standard } \\
\text { errors }\end{array}$ & Fix-renter & $\begin{array}{c}\text { Standard } \\
\text { errors }\end{array}$ \\
\hline Age & $0.039^{*}$ & 0.02 & $-0.095^{* *}$ & 0.04 \\
Gender & $-0.820^{*}$ & 0.46 & $0.880^{* *}$ & 0.43 \\
Education & $0.376^{* * *}$ & 0.08 & $-0.273^{* * *}$ & 0.08 \\
Family & 0.028 & 0.03 & $0.296^{* *}$ & 0.15 \\
Size & & & & \\
Animals & $0.024^{*}$ & 0.01 & $-0.169^{* *}$ & 0.07 \\
Land & $0.069^{* * *}$ & 0.01 & $-0.462^{* *}$ & 0.21 \\
Credit & -0.283 & 0.19 & -0.126 & 0.59 \\
Soil & $0.009^{* *}$ & 0.00 & -0.010 & 0.02 \\
Quality & & & & \\
Location 1 & -0.344 & 0.41 & -0.310 & 0.54 \\
Location 2 & -0.485 & 0.39 & 0.250 & 0.45 \\
Location 3 & -0.615 & 0.44 & 0.596 & 0.43 \\
Location 4 & -0.875 & 0.69 & 0.039 & 0.81 \\
\hline
\end{tabular}

The results also show that physical assets like land, farm equipment and human capital like education have positive and 
Table 3. Instrumental variable estimates of determinants of land productivity, per head expenditure and poverty level.

\begin{tabular}{lcccc}
\hline Variable & Crop Productivity & $\begin{array}{c}\text { Livestock } \\
\text { Productivity }\end{array}$ & Per Head Expenditure & Poverty \\
\hline Owner & $1.872(3.53)^{* * *}$ & $0.442(3.99)^{* * *}$ & $1.603(2.24)^{* * *}$ & $-1.419(4.16)^{* * *}$ \\
Fix-renter & $1.344(4.02)^{* * *}$ & $0.762(2.01)^{* *}$ & $1.290(1.82)^{*}$ & $-1.247(1.92)^{*}$ \\
Land & $0.092(1.68)^{* *}$ & $1.583(1.80)^{*}$ & $0.037(2.26)^{* *}$ & $-0.040(1.67)^{*}$ \\
Soil Fertility & $0.159(1.85)^{*}$ & $0.970(1.72)^{*}$ & $0.142(0.92)$ & $-0.010(2.93)^{* * *}$ \\
Credit & $0.986(2.46)^{* *}$ & $0.076(1.91)^{*}$ & $0.369(2.07)^{* *}$ & $-0.018(3.11)^{* * *}$ \\
Gender & $0.031(0.32)$ & $0.117(2.12)^{* *}$ & $0.515(0.47)$ & $-0.052(0.73)$ \\
Age & $0.071(1.72)^{*}$ & $0.037(0.86)$ & $0.057(2.01)^{* *}$ & $-0.054(2.23)^{* *}$ \\
Education & $0.086(4.46)^{* * *}$ & $0.573(1.75)^{*}$ & $0.357(1.70)^{*}$ & $0.323(2.45)^{* *}$ \\
Family Size & $0.059(1.70)^{* *}$ & $0.929(2.30)^{* *}$ & $0.651(2.32)^{* * *}$ & $0.079(1.82)^{*}$ \\
location1 & $0.657(1.35)$ & $0.258(1.45)$ & $0.094(0.15)$ & $5.009(2.72)^{* *}$ \\
location2 & $0.799(1.67)^{*}$ & $-0.569(2.04)^{*}$ & $-0.129(0.21)$ & $1.802(1.37)$ \\
location3 & $0.156(0.34)$ & $0.742(0.75)$ & $-0.437(0.80)$ & $1.114(1.04)$ \\
location4 & $0.524(0.71)$ & $0.256(0.09)$ & $0.049(0.07)$ & $-0.089(0.05)$ \\
location5 & $-1.251(2.99)^{* *}$ & $0.925(0.53)$ & $0.961(1.63)$ & $0.228(0.22)$ \\
Constant & $3.953(3.49)^{* * *}$ & $2.926(1.66)^{*}$ & $6.612(2.30)^{* *}$ & $1.896(1.49)$ \\
Adjusted $R^{2}$ & 0.248 & 0.321 & 0.294 & 0.310 \\
Wald-statistics $\chi^{2}{ }^{2} 4$ & 10.980 & 12.560 & 5.690 & 4.260 \\
F-value & 48.990 & 74.560 & 102.250 & 98.350 \\
Prob>F & 0.000 & 0.000 & 0.000 & 0.000 \\
Number of & 341 & 341 & 341 & 341 \\
observations & & & & \\
\hline Note: Significance of coefficients is at the $* 10 \%, * * 5 \%$ and $* * * 1 \%$ levels. Predicted values of tenancy arrangement variables are used.
\end{tabular}

significant impact on per head expenditure, farm productivity and have negative and significant impact on poverty level.

Conclusion: This study utilized cross-sectional data of 341 rural household of Pakistan to examine the effects of tenancy arrangements on the farm productivity, per head expenditures and poverty level of the households. Secured property rights tend to increase the farm productivity and household welfare while it contributes to reduce poverty level of the households. These findings emphasize the strengthening of secured land rights in rising household welfare and agricultural productivity. Policy makers should target the poor landless rural people to improve the access to land, which is critical to promote welfare and reduce poverty.

The results also indicate that education has positive and significant impact on per head expenditure, farm productivity and negative and significant impact on poverty level. Hence, it is very crucial for the government to focus on education, especially in remote rural areas which will ultimately lead to growth and productivity of agricultural sector.

Access to credit has significant and positive impact on crop and livestock productivity, suggesting to overcome financial constraints of resource poor farmers in rural areas where imperfect credit markets are functioning. In short, there is need of revisiting the issue of land tenure security and access to credit by formulating and implementing land reforms in Pakistan.

\section{REFERENCES}

Ayalew, L., H. Yamagishi, H. Marui and T. Kanno. 2005. Landslides in Sado Island of Japan: Part II. GIS-based susceptibility mapping with comparisons of results from two methods and verifications. Eng. Geol. 81:432-445.

Deininger, K. and S. Jin. 2006. Tenure security and landrelated investment: Evidence from Ethiopia. Eur. Econ. Rev. 50:1245-1277.

Deininger, K., S. Jin and H.K. Nagarajan. 2009. Land reforms, poverty reduction, and economic growth: Evidence from India. J. Dev. Stud. 45:496-521.

Feder, G. and D. Feeny. 1991. Land tenure and property rights: Theory and implications for development policy. World Bank Econ. Rev. 5:135-153.

Javaid, U. 2017. Role of mass media in promoting agricultural information among farmers of district nankana. Pak. J. Agri. Sci. 3: 711-715.

Kousar, R and A. Abdulai. 2015. Off-farm work, land tenancy contracts and investment in soil conservation measures in rural Pakistan. Aust. J. Agric. Resour. Econ. 59:1-19.

Ministry of Finance. 2012. Economic Survey of Pakistan 2011-12. Finance and Economic Affairs Division, Ministry of Finance, Govt. of Pakistan, Islamabad, Pakistan. 
Ministry of Finance. 2015. Economic Survey of Pakistan 2014-15. Finance and Economic Affairs Division, Ministry of Finance, Govt. of Pakistan, Islamabad, Pakistan.

Rehman, M. 1987. Women and rural development in Pakistan. J. Rural Stud. 3:247-243.
United States Agency for International Development. 2010. USAID Country Profile: Property rights and resource governance, Pakistan. Land Tenure and Property Rights Portal. 